УДК 343.9

DOI https://doi.org/10.32837/apdp.v0i87.2817

O.І.Хороновський

\title{
СТРУКТУРНІ ОЗНАКИ СУЧАСНИХ ТРАНСНАЦІОНАЛЬНИХ ОРГАНІЗОВАНИХ ЗЛОЧИННИХ УГРУПОВАНЬ, ЯКІ ФУНКЦІОНУЮТЬ НА ШКОДУ ЕКОНОМІЧНИМ ІНТЕРЕСАМ ДЕРЖАВИ
}

Постановка проблеми. На сучасному етапі, через еволюцію злочинної діяльності, питання протидії транснаціональній злочинності набувають неабиякої актуальності та посідають важливе місце у становленні правової держави, її інтеграції у світову спільноту, що є неможливим без забезпечення активної наступальної протидії злочинності та досягнення уповільнення темпів їі зростання на основі чітко визначених пріоритетів, поступового нарощування зусиль міжнародних інституцій, держави і громадськості, удосконалення законодавства, організації засобів і методів відвернення та розкриття злочинів.

Особливість транснаціональних організованих злочинних угруповань пояснюється тим, що останні зазвичай завдають шкоди своєю діяльністю не лише окремим фізичним або юридичним особам, а несуть небезпеку для галузей народного господарства окремих держав та їхніх національних економік загалом.

Аналіз останніх досліджень і публікацій. Питанням організованої злочинності загалом та транснаціональної організованої злочинності зокрема присвячували свої праці досить багато дослідників. Теоретичним основам протидії транснаціональній організованій злочинності присвячено роботи М.Г. Вербенського, О.М. Бандурки, В.В. Голіни, О.М. Джужи, О.Ф. Долженкова, В.М. Дрьоміна, Г.П. Жаровської, А.П. Закалюка, Н.А. Зелінської, О.В.Козаченко, В.П. Коржа, Г.П. Пожидаєва, І.В. Пшеничного, Е.В. Расюка, Є.Д. Скулиша, Є.Л. Стрельцова, М.I. Хавронюка й інших.

Визнаємо значущість здобутків означених науковців, з урахуванням масштабного реформування законодавства, системи правоохоронних та судових органів, системних перетворень у державній антикорупційній та фіскальній політиці, варто зазначити, що дотепер так і не вироблено загальновизнаного розуміння транснаціональних організованих злочинних угруповань, чітко не окреслено їхніх структурних ознак.

Нині у вітчизняній правничій науці фактично немає спеціальних досліджень, що стосуються саме структурних ознак транснаціональних організованих злочинних угруповань, які, зокрема, функціонують на шкоду економічним інтересам держави. Наявні ж напрацювання зазвичай висвітлюють лише окремі підходи до цього питання, стосуються в основному загального поняття транснаціональної організованої злочинності без конкретизації сфери її діяльності.

Метою статті є виокремлення структурних ознак саме транснаціональних злочинних угруповань, які функціонують на шкоду економічним інтересам держави.

Виклад основного матеріалу дослідження. Для дослідження структурних ознак сучасних транснаціональних організованих злочинних угруповань, які функціо- 
нують на шкоду економічним інтересам держави, уважаємо за доцільне використати структурно-функціональний метод, який, на наш погляд, дозволить найбільш повно розкрити їхні сутнісні ознаки.

Структурно-функціональний метод - це підхід в описі і поясненні систем, за якого досліджуються їхні елементи і залежності між ними в рамках єдиного цілого. Кожен елемент цієї структури виконує визначені функції, що задовольняють потреби системи. Діяльність елементів системи програмується загальною структурною організацією, займаними ними позиціями і виконуваними ролями [1].

Структурний підхід передбачає визначення кількісного складу учасників транснаціональних злочинних об'єднань, їхнього опису і характеру взаємозв'язків.

Структура злочинного об'єднання - це його внутрішня побудова, яка визначається відповідною конфігурацією і змістом стійких зв'язків учасників об'єднання та забезпечує психологічну єдність і стабільність останнього [2].

Чинний Кримінальний кодекс України виділяє дві форми організованої злочинності, які по своїй суті можуть бути транснаціональними: організована група якщо в готуванні або вчиненні злочину брали участь декілька осіб (три і більше), які попередньо зорганізувалися у стійке об'єднання для скоєння цього й іншого (інших) злочинів, об'єднаних єдиним планом із розподілом функцій учасників групи, спрямованих на досягнення цього плану, відомого всім учасникам групи, та злочинна організація - якщо злочин скоєний стійким ієрархічним об'єднанням декількох осіб (п'ять і більше), члени якого або структурні частини якого за попередньою змовою зорганізувалися для спільної діяльності з метою безпосереднього вчинення тяжких або особливо тяжких злочинів учасниками цієї організації або керівництва чи координації злочинної діяльності інших осіб, або забезпечення функціонування як самої злочинної організації, так і інших злочинних груп [3].

На відміну від національного законодавства Конвенція Організації Об’єднаних Націй (далі - ООН) проти транснаціональної організованої злочинності (далі - Конвенція) виділяє лише одну форму організованої злочинності - організована злочинна група, під якою розуміє структурно оформлену групу у складі трьох або більше осіб, що існує протягом визначеного періоду часу і діє узгоджено з метою здійснення одного або декількох «серйозних» злочинів, визнаних такими відповідно до цієї Конвенції, для того, щоб одержати, прямо або посередньо, фінансову або іншу матеріальну вигоду [4].

Отже, у структурному плані можна виокремити принаймні два основні рівні організованості транснаціональних злочинних формувань, які функціонують на шкоду економічним інтересам держави.

Перший рівень - організована група, яка має елементарну структуру: «керівник - учасники, або виконавці». Така група вчинює зазвичай злочини, що не потребують особливої підготовки. Рівень злочинного професіоналізму таких груп відносно невисокий, вони чисельно невеликі, рідко мають корумповані зв’язки (якщо такі є, то службовий статус корумпованих осіб невисокий).

Другий рівень - злочинна організація з вищою функціональною диференціацією, ієрархічністю, розподілом ролей, зазвичай наявністю корумпованих зв'язків у державному апараті та правоохоронних органах. Чисельність їх досить велика 
(до кількох десятків осіб), що і дає змогу забезпечувати певну структуризацію групи (організатори - «мозковий центр», технічні виконавці, «силовий блок», «прикриття і забезпечення», юридичний та бухгалтерський супровід та інші варіанти).

Транснаціональний характер структурної організованості злочинного об'єднання, з урахуванням положення ст. 3 Конвенції, полягає в тому, що один із його учасників учиняє злочинні діяння в більш ніж одній державі, зокрема й тоді, коли більша частина їх підготовки, планування, керівництва або контролю має місце в іншій державі. Водночас не є обов'язковою умовою факт перетинання злочинцями державних кордонів або постійне місце дислокації за кордоном, якщо мають місце істотні наслідки в іншій державі [4].

3 урахуванням вищезазначеного, характерні структурні ознаки транснаціональної організованої злочинності на шкоду економічним інтересам держави умовно можемо розділити на дві групи: загальні - які характерні для всіх видів транснаціональної організованої злочинності, та спеціальні - характеризують безпосередньо діяльність транснаціональних організованих злочинних угруповань, які функціонують на шкоду економічним інтересам держави.

До загальних рис відносимо такі:

1) стійкість. Стійкість злочинних формувань означає їхню здатність протидіяти зовнішнім та внутрішнім чинникам, забезпечувати свою функціональність та стабільність протягом певного проміжку часу;

2) ієрархічність. Сутністю ієрархічності організованого злочинного угруповання є характер взаємин між його учасниками, який будується на принципах підпорядкованості, дотриманні певних правил поведінки та досягнення спільної мети;

3) розподіл функиій та ролей. Розподіл функцій у злочинному об’єднанні це розподіл обов'язків між його учасниками під час спільного вчинення злочинів. Розподіл ролей у злочинному об’єднанні - це розподіл обов'язків між різними видами співучасників під час учинення злочинів. Розподіл ролей визначає структуру злочинного об'єднання та є різновидом розподілу функцій між різними видами співучасників;

4) спеціальна мета. Під спеціальною метою розуміється вчинення одного або кількох злочинів для того, щоб отримати будь-яку матеріальну вигоду.

Серед спеціальних ознак транснаціональних організованих злочинних угруповань, які функціонують на шкоду економічним інтересам держави виділяємо:

1) наявність спеціального суб’єкта злочину. Суб’єкти злочинної діяльності (в основному організатори та виконавці) характеризуються наявністю спеціальних знань та навичок у сфері економічної діяльності. Зазвичай це особи, які мають певний досвід роботи у сфері юриспруденції, бухгалтерії, менеджменту, інтелектуальних технологій, маркетингової діяльності тощо.

У теорії кримінального права серед суб'єктів таких злочинів залежно від обов’язкових і додаткових якостей (які мають бути властиві такій особі: за місцем такої особи у структурі об'єкта, її правами й обов'язками, які покладені на неї правовими приписами) науковцями виділяється три основні категорії: будь-яка особа, що підлягає кримінальній відповідальності, яка порушує або не виконує певні 
обов’язки у сфері економічної діяльності; спеціальні суб'єкти; спеціально-конкретні суб'єкти [5, с. 112]. Будь-яка особа, що підлягає кримінальній відповідальності, яка порушує або не виконує певні обов'язки, за своїм юридичним змістом є загальним суб'єктом злочину, тому окремої кримінально-правової характеристики не потребує. У свою чергу, спеціальних (спеціально-конкретні суб'єкти злочину) за юридичним змістом їхніх додаткових ознак можна розподілити на три підгрупи: службові особи; фізичні особи, які не оформили статусу юридичної особи; інші особи у сфері економічної діяльності з ознаками спеціального суб’єкта;

2) високий рівень латентності. Порівняно з багатьма іншими кримінальними правопорушеннями злочинам, які вчиняються транснаціональними організованими злочинними угрупованнями на шкоду економічним інтересам держави, властива значно більша латентність, яка залежить від двох чинників - окремих характерних властивостей осіб, що вчинюють такі злочини. Перший із них - це значний рівень інтелектуального розвитку, наявність якого в разі вчинення злочинів дозволяє ретельно планувати таку суспільно небезпечну діяльність, тривалий час залишати її невикритою правоохоронними органами. Другий - досить високий у загальному плані соціальний статус цілої низки суб'єктів таких злочинів, у зв'язку із чим така злочинність у західних країнах часто зветься «білокомірцевою» [6].

Закордонними дослідниками зверталася увага на велику схожість злочинців у «білих комірцях» з особами, які не скоїли жодних злочинів. Порівняно з іншими такі злочинці значно менше разів були захоплені на місці вчинення злочинів, рідше арештувалися, проти них висувалося менше обвинувачень, вони рідше потрапляли у в'язницю, а строки їх ув'язнення були значно менш тривалими, ніж у злочинців інших категорій. Такі злочинці були старшими за віком, ніж інші, серед них було більше жінок, вони частіше були пов'язані родинними зв'язками та мали більше дітей. У порівнянні з іншими злочинцями «білі комірці» значно рідше вчинювали злочини та взагалі були менш схильні до скоєння правопорушень, менше вживали алкогольних напоїв, і набагато менше - наркотиків [7, с. 20-21].

Отже, характер такої протиправної діяльності має завуальований характер і здебільшого вона коїться під виглядом легальної фінансово-господарської діяльності з урахуванням усіх можливих прогалин та колізій вітчизняного та міжнародного законодавства, у зв'язку із чим виявити ознаки такої діяльності без наявності спеціальних знань та відповідної підготовки практично неможливо;

3) наявність фінансових ресурсів. У даному контексті фінансові ресурси трактуємо як власний або позичковий капітал у грошовій чи будь-якій іншій формі, який перебуває у розпорядженні організованого злочинного угруповання та використовується з метою реалізації злочинного умислу. Такі ресурси залежно від категорії складності вчинюваних злочинів можуть спрямовуватись на: оренду приміщень, придбання комп'ютерної техніки, реєстрацію суб'єктів господарювання, відкриття та купівлю компаній-нерезидентів, відрядження за кордон, найм працівників (здебільшого «фунтів» - номінальних керівників та засновників підприємств), виготовлення печаток (бланки, штампи тощо), підкуп службових осіб контролюючих органів (у нашому випадку це можуть бути працівники органів фіскальної служби, фінансової розвідки, національних регуляторів банківської 
системи, фондового ринку, ринку фінансових послуг тощо), відкриття банківських рахунків тощо;

4) високий рівень конспірацї. Конспірація в даному разі є своєрідним комплексом режимних заходів, який уживається всіма учасниками злочинного формування, спрямований на збереження в таємниці факту його існування та характеру протиправної діяльності. Одним з основних сучасних елементів конспірації $\epsilon$ шифроване цифрове спілкування учасників злочинного угруповання за допомогою мобільних додатків (Viber, Skype, WhatsApp, Imo, Signal, Threema, Telegram та інших). Також можуть розроблятись власні програми для конспіративного спілкування обмеженого кола осіб;

5) наявність власної служби безпеки. Зазвичай транснаціональні злочинні угруповання мають у розпорядженні власні служби безпеки, до складу яких входять особи, які часто мають досвід роботи у правоохоронних органах, поінформовані про форми і методи роботи правоохоронних органів, оснащені засобами виявлення технічних пристроїв із негласного зняття інформації, мають неофіційний доступ до баз даних державних органів, систематично проводять заходи з контрспостереження тощо;

6) наявність корулпованих зв'язків. Транснаціональні злочинні угруповання корумпують як національних, так і іноземних посадових осіб із метою отримання можливості вести або продовжувати економічну діяльність у якій-небудь країні або отримувати які-небудь преференції.

Президентська комісія із дотримання закону і здійснення правосуддя у Сполучених Штатах Америки встановила: «Усі наявні дані вказують на те, що організована злочинність процвітає там, де нею підкуплені місцеві посадові особи. Перебувати на утриманні організованої злочинності - звичний стан місцевої влади і політичних діячів. Ні політичні діячі, ні обвинувачі, ні навіть судді, - за словами відомого норвезького юриста I. Анденеса, - не гарантовані від спокуси. Чим більше поширюється корупція, тим важче з нею боротися. Кожен, хто надає відомості про корупцію, ризикує тим, що він повідомляє їх одному з тих, кого підкуповують. Отже, організована злочинність досягла успіху у створенні імунітету від покарання за допомогою підкупу правоохоронних органів і встановлення власної системи залякування» [8, с. 412-413].

Висновки. Виділені нами структурні ознаки транснаціональних організованих злочинних угруповань, які функціонують на шкоду економічним інтересам держави, свідчать про високий рівень еволюції транснаціональних злочинних елементів та необхідність в удосконаленні форм та методів боротьби з ними. Запропоновані структурні ознаки не є вичерпними, залежать від багатьох об’єктивних та суб'єктивних чинників. Подальшими перспективними дослідженнями можуть бути структурні елементи діяльності транснаціональних організованих злочинних угруповань в економічній сфері вузької спеціалізації, як-от банківська система, ринок цінних паперів, небанківські фінансові послуги тощо. 


\section{Jimepamypa}

1. Структурно-функціональний аналіз та моделювання розвитку економіки : монографія / В.К. Галіцин та ін. Київ : КНЕУ, 2013. 377 с.

2. Корнієнко М.В. Організована злочинність в Україні : сучасний стан, кримінологічна характеристика, заходи протидії. Київ : Фонд Юрнауки, 2004. 300 с.

3. Кримінальний кодекс України. Відомості Верховної Ради України. URL: http://zakon3.rada. gov.ua/laws/show/2341-14.

4. Конвенція $\mathrm{OOH}$ проти транснаціональної організованої злочинності. Прийнята резолюцією 55/25 Генеральної Асамблеї від 15 листопада 2000 р. Відомості Верховної Ради України URL: https://zakon.rada.gov.ua/laws/show/995_789\#Text.

5. Жаровська Г.П. Співучасть у злочині за кримінальним правом України : дис. ... канд. юрид. наук: 12.00 .08 . Київ, 2004. $211 \mathrm{c.}$

6. Кузнецова Т.К. Офшорні операції як чинник тінізації економіки. Украӥнський соиіул. 2009. № 4 (31). C. 70-73.

7. Podgor E., Israel J. White Collar Crime in a Nutshell. St. Paul : West Group, 1997. 452 p.

8. Михайлов 0.Є., Горбань А.В., Міщук В.В. Кримінологія : навчальний посібник. Київ : Знання, $2012.565 \mathrm{c}$.

\section{Анотація}

Хороновський O. I. Структурні ознаки сучасних транснаціональних організованих злочинних угруповань, які функціонують на шкоду економічним інтересам держави. - Стаття.

У статті розглянуто питання структурної побудови сучасних транснаціональних організованих злочинних угруповань, які функціонують на шкоду економічним інтересам держави. Виділено два основні рівні іххньої організованості. Перший рівень - організована група, яка має елементарну структуру: «керівник - учасники, або виконавці». Рівень злочинного професіоналізму таких груп відносно невисокий, вони чисельно невеликі, рідко мають корумповані зв'язки. Другий рівень - злочинна організація з вищою функціональною диференціацією, ієрархічністю, розподілом ролей, наявністю зазвичай корумпованих зв'язків у державному апараті та правоохоронних органах. Чисельність їх досить велика, що і дає змогу забезпечувати певну структуризацію групи: організатори - «мозковий центр», технічні виконавці, «силовий блок», "прикриття і забезпечення», юридичний та бухгалтерський супровід й інші варіанти.

Визначено, що транснаціональний характер структурної організованості злочинного об'єднання полягає в тому, що один із його учасників учиняє злочинні діяння в більш ніж одній державі, зокрема й коли більша частина їх підготовки, планування, керівництва або контролю має місце в іншій державі. Водночас не є обов'язковою умовою факт перетинання злочинцями державних кордонів або постійне місце дислокації за кордоном, якщо мають місце істотні наслідки в іншій державі.

Запропоновано умовний поділ їхніх структурних ознак на загальні, які характерні для всіх видів транснаціональної організованої злочинності, зокрема: стійкість, ієрархічність, розподіл функцій та ролей, спеціальна мета, та спеціальні - характеризують безпосередньо діяльність транснаціональних організованих злочинних угруповань, які функціонують на шкоду економічним інтересам держави, а саме: спеціальний суб'єкт злочину, високий рівень латентності, наявність фінансових ресурсів, високий рівень конспірації, власна служба безпеки, корумповані зв'язки. Надано характеристику визначених загальних та спеціальних структурних ознак.

Ключові слова: форма організованої злочинності, рівень організованості, структура злочинного об'єднання, учасник злочинного формування, транснаціональний характер, корумповані зв'язки, «білокомірцева злочинність» .

\section{Summary}

Khoronovskyi $O$. I. Structural features of modern transnational organised criminal groups which harms state economic interests. - Article.

The article goes on the structural construction of modern transnational organised criminal groups which harms state economic interests. The two main levels of their organization are defined. The first level concerns an organised group, which has an elementary structure: "manager - participants, or executers". The level of criminal professionalism of these groups is relatively low, they are numerically not large, rarely use corruption connections. The second level concerns criminal organisations with higher functional differentiation, hierarchy, distribution of functions and roles and as rule availability of corruption connec- 
tions in state apparatus and law enforcement bodies. The number of these groups is big enough, that enables some structuring: organiser - "think tank", technical executers, "power unit”, "cover and security', legal and accounting support etc.

It is defined that transnational character of structural organization of criminal association is that one of its participants commits criminal actions in more than one country, including when most of preparation, planning, management or control takes place in another country. Herewith crossing the state border by criminals or their permanent location abroad is not necessary factor, if there are significant consequences in another country.

It is proposed the conditional divide of structural features of modern transnational organised criminal groups which harms state economic interests by general and special. General features characterise all types of transnational organised crime, especially resistance, hierarchy, distribution of roles, special purpose. Special features characterise directly the activity of transnational organised criminal groups which harms state economic interests, especially special perpetrator of an offence, high level of latency, financial recourses, high level of conspiracy, own security service, corruption connections. Given a description of defined general and special structural features of modern transnational organised criminal groups which harms state economic interests.

Key words: form of organised crime, level of organization, structure of criminal association, participant in criminal group, transnational character, corruption connections, "white-collar crime". 